\title{
Streptokinase production from Streptococcus dysgalactiae subsp. equisimilis SK-6 in the presence of surfactants, growth factors and trace elements
}

\author{
Shilpi Bhardwaj · Jayaraman Angayarkanni
}

Received: 9 February 2014 / Accepted: 8 March 2014/Published online: 20 March 2014

(c) The Author(s) 2014. This article is published with open access at Springerlink.com

\begin{abstract}
Streptokinase is an extracellular protein secreted by various strains of streptococci and is used clinically as an intravenous thrombolytic agent for the treatment of acute myocardial infarction. It is well established that the fibrinolytic activity of streptokinase originates in its ability to activate plasminogen. The present investigation was carried out to determine the extent of streptokinase production by Streptococcus dysgalactiae subsp. equisimilis SK-6, in the presence of surfactants, growth factors, trace elements and under the influence of different physical parameters. Mineral salt medium was supplemented with different surfactants, growth factors and trace elements. Effects of incubation period and inoculum volume were also studied. Results indicated that the streptokinase yield was higher in the presence of non-ionic surfactants, where Tween 80 supported maximum enzyme production $(0.178 \mathrm{U} / \mathrm{ml})$. Growth factors such as glycine and thiamine supplementation resulted in better enzyme production. Trace elements in the form of magnesium sulphate and ferrous sulphate when added in lesser quantity aided higher streptokinase synthesis. Enzyme production was severely affected in the presence of higher concentrations of these inorganic salts. A constant decrease in the enzyme production was observed beyond $48 \mathrm{~h}$ of incubation. Among the different inoculum sizes used, $1 \% \mathrm{v} / \mathrm{v}$ inoculum facilitated highest streptokinase production $(0.360 \mathrm{U} / \mathrm{ml})$. The streptokinase production ability of $S$. dysgalactiae
\end{abstract}

S. Bhardwaj ( $\square)$

Department of Microbiology, Karpagam University,

Coimbatore 641021, Tamil Nadu, India

e-mail: shilpibh2003@gmail.com

J. Angayarkanni

Department of Microbial Biotechnology, Bharathiar University,

Coimbatore 641046, Tamil Nadu, India subsp. equisimilis SK-6 offers its potential industrial application for the manufacture of streptokinase.

Keywords Streptokinase - Streptococcus dysgalactiae subsp. equisimilis SK-6 · Surfactants · Growth factors . Trace elements

\section{Introduction}

Cardiovascular diseases are one of the biggest health concerns all over the world (Grundy et al. 1999). Among these, thrombosis is most widespread within the elderly population. The disease results from severe blood clotting, leading to the obstruction of blood circulation. In the physiological state, fibrin and platelets are utilized for clotting to prevent blood loss from injuries in a process called haemostasis (Furie and Furie 2008).

A blood clot or thrombus contains a mixture of platelets, fibrin and in some cases red blood cells and are of two types: platelet-rich arterial clots (also called white clots) formed under high shear stress, typically after rupture of an atherosclerotic plaque or other damage to the blood vessels and venous clots (also called red clots) containing red blood cells and formed under lower shear stress on the surface of a largely intact endothelium. Both these clots can be treated with anticoagulant and anti-platelet drugs (Mackman 2012).

In order to properly terminate the haemostasis, a serine protease called plasmin digests blood clots via fibrinolysis. Plasmin deficiency may lead to thrombosis due to insufficient degradation of clots (Phan et al. 2011). The most rational treatment for acute myocardial infarction is likely to be the rapid administration of thrombolytic agents with or without procedures that produce persistent recanalization without rethrombosis (Tharwat 2006). 
Among various thrombolytic agents, streptokinase is most effective in dissolving newly formed clots. Streptokinase is an enzyme produced by many strains of $\beta$-haemolytic streptococci isolated naturally from upper respiratory tract and is used to dissolve the fibrin matrix of blood clots, especially those in the arteries of the heart and lungs. Being a non-fibrin specific extracellular enzyme, it exerts its fibrinolytic action indirectly by activating the circulatory plasminogen (Banerjee et al. 2004).

Streptokinase has a molecular weight of $47 \mathrm{kDa}$ and is made up of single-chain polypeptide of 414 amino acid residues. It is composed of three distinct domains, denoted as $\alpha$ (residues 1-150), $\beta$ (residues 151-287) and $\gamma$ (residues 288-414). The exponential increase in the application of streptokinase in various fields in the last few decades demands extension in both qualitative improvement and quantitative enhancement (Abdelghani et al. 2005).

In this study, we report the effect of various surfactants, growth factors, trace elements, incubation period and inoculum size on the production of streptokinase by Streptococcus dysgalactiae subsp. equisimilis SK-6.

\section{Materials and methods}

Chemicals and reagents

All the fine chemicals used were purchased from SRL Chemicals, India and were of the highest purity and analytical grade.

Inoculum preparation

Streptococcus dysgalactiae subsp. equisimilis SK-6 (GenBank accession no. KF312378) was inoculated in $10 \mathrm{ml}$ of mineral salt medium (MSM) (g/l: glucose, 5.0; yeast extract, 5.0; $\mathrm{KH}_{2} \mathrm{PO}_{4}, 2.5 ; \mathrm{MgSO}_{4} \cdot 7 \mathrm{H}_{2} \mathrm{O}, 0.4 ; \mathrm{NaHCO}_{3}$, 1.0; $\mathrm{CH}_{3} \mathrm{COONa} \cdot 3 \mathrm{H}_{2} \mathrm{O}, 1.0 ; \mathrm{FeSO}_{4} \cdot 7 \mathrm{H}_{2} \mathrm{O}, 0.02 ; \mathrm{MnCl}_{2}$. $4 \mathrm{H}_{2} \mathrm{O}, 0.02 ; \mathrm{pH} 7.4$ ) and incubated at $37{ }^{\circ} \mathrm{C}$ for $24 \mathrm{~h}$. Following the development of turbidity, $1 \%$ of the culture was used as inoculum (Baewald et al. 1975).

Results from our previous study showed that amending the MSM with carbon and nitrogen sources such as glucose $(1.0 \% \mathrm{w} / \mathrm{v})$ and tryptone $(1.5 \% \mathrm{w} / \mathrm{v})$, respectively, and an initial pH 7.0 followed by incubation at $37{ }^{\circ} \mathrm{C}$ enhanced the streptokinase production by $S$. dysgalactiae subsp. equisimilis SK-6 (Bhardwaj et al. 2013).

Effect of chemical and physical parameters on streptokinase production

Effect of surfactants on streptokinase production by $S$. dysgalactiae subsp. equisimilis SK-6 was studied by incorporation of $0.05 \%(\mathrm{v} / \mathrm{v})$ of Tween 20, Tween 40, Tween 80, Triton X-100 and $0.05 \%(w / v)$ sodium lauryl sulphate (SLS) and sodium deoxycholate (SDC) to the modified MSM. Growth factors like thiamine, riboflavin, nicotinic acid, tryptophan, glycine and L-lysine $(0.1 \% \mathrm{w} / \mathrm{v})$ were used. Influence of $\mathrm{MgSO}_{4} \cdot 7 \mathrm{H}_{2} \mathrm{O}(0.02,0.04,0.06$, 0.08 and $0.10 \% \mathrm{w} / \mathrm{v})$ and $\mathrm{FeSO}_{4} \cdot 7 \mathrm{H}_{2} \mathrm{O}(0.002,0.004$, $0.006,0.008$ and $0.010 \% \mathrm{w} / \mathrm{v})$ were studied. Effects of incubation period $(24,48,72,96$ and $120 \mathrm{~h})$ and inoculum size $(0.05,0.1,0.3,0.5,1.0,1.5$ and $3.0 \% \mathrm{v} / \mathrm{v})$ were optimized.

\section{Streptokinase activity}

Following incubation under optimized conditions, the cultures were centrifuged at $10,000 \mathrm{~g}$ for $30 \mathrm{~min}$. The cellfree supernatant was filtered through $0.45 \mu \mathrm{m}$ cellulose acetate filter and the filtrate was considered as crude enzyme (Babashamsi et al. 2009).

Streptokinase activity was determined indirectly by casein digestion method, which is based on determination of the liberated tyrosine from digested casein (Mounter and Shipley 1958). One unit (U/ml) of streptokinase activity was defined as the amount of enzyme releasing $1 \mu \mathrm{mol}$ of tyrosine equivalent/min. The soluble protein content of the enzyme sample was measured at $660 \mathrm{~nm}$ using a spectrophotometer. A standard curve was prepared using bovine serum albumin as standard protein (Lowry et al. 1951).

Statistical analysis

All the optimization studies were conducted in triplicate and the data were analyzed using single factor analysis of variance (ANOVA). All the data are graphically presented as the mean \pm standard deviation (SD) of triplicates $(n=3)$. ANOVA was performed using Microsoft Excel 2007. $P$ values $<0.05$ were considered significant with a confidence limit of $95 \%$.

\section{Results and discussion}

Rapid and higher enzyme production can be achieved by improvement in media composition and physical parameters (Oberoi et al. 2001). Accurate process optimization influences the activities of microorganisms and improves the production significantly, which is desirable for minimizing the processing cost. In biotechnological enzyme production processes, even small improvements have been significant for commercial success (Reddy et al. 2008). 
Effect of surfactants on streptokinase production

Surfactants have a variety of applications in microbial bioprocessing operations. Surfactants promote increased production of extracellular products through interaction with cell membrane components during the fermentation step (Rao and Satyanarayana 2003). The modulating impacts of surfactants on enzyme yield, activity, specificity and stability may thus be exploited in industrial enzymology. The general impact of surfactants in promotion of protein secretion is likely to involve interactions with the lipid components of cell membranes in a manner which facilitates secretion. Thus surfactants represent a valid option to be considered when microbial processes for production of extracellular proteins are being developed, especially where rate of protein secretion is a barrier (Singh et al. 2007).

In the present study, as compared to the anionic surfactants like SLS and SDC, non-ionic surfactants such as Tween 20, Tween 80 and Triton X-100 proved to be superior in enhancing streptokinase production. Among the different surfactants used, highest streptokinase activity $(0.178 \mathrm{U} / \mathrm{ml})$ was recorded in the presence of Tween 80 (0.05\% v/v) (Fig. 1).

Tween 80 proved to be the best surfactant in $S$. dysgalactiae subsp. equisimilis SK-6 mediated streptokinase production possibly because of its chemical structure. Unlike other non-ionic surfactants, Tween 80 possesses greater chain length, which in turn increased its aqueous solubility thereby reducing the intensive interaction between itself and hydrophobic cell membrane. Addition of Tween 80 at a concentration of $0.01-0.10 \%$ to the medium prior to inoculation has been recommended for achieving high titers of streptokinase which was on par with our results (Banerjee et al. 2004).

The probable reason for non-ionic surfactants enhancing streptokinase production in the present study could be due to the molecular structure of surfactants which determines varying degrees of toxicity to microbial cells. Literatures

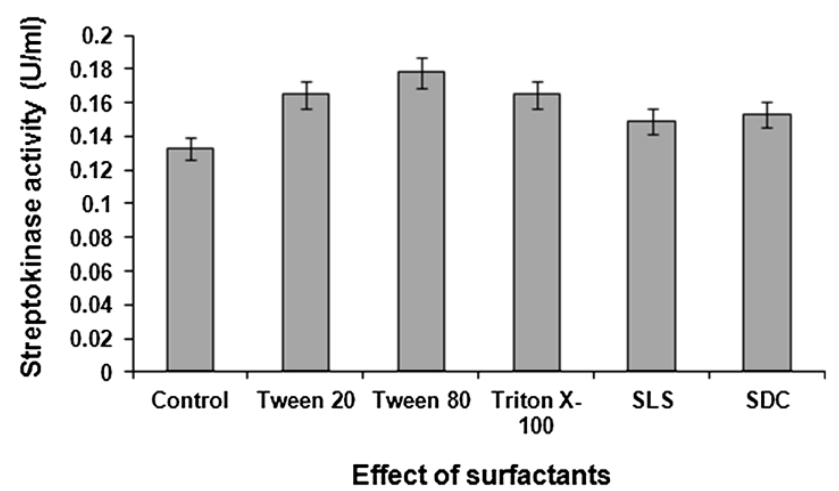

Fig. 1 Effect of different surfactants on streptokinase production. Data represent mean $\pm \mathrm{SD}(n=3) ; P<0.05$ suggested that non-ionic surfactants due to their low cytotoxicity were better choices for enhancing the enzyme production. Polyoxyethylene sorbitan surfactants (Tween series) have been shown to possess low toxicity (Singh et al. 2007). Generally, surfactant toxicity becomes lower as the chain length increases, i.e. an increasing hydrophilicity (Jurado et al. 2009).

\section{Effect of growth factors on streptokinase production}

Specific manipulations of the culture medium have been shown to enhance protein release into the medium. In the selection of a medium for economic production of streptokinase, various materials have been suggested.

Among the amino acids, glycine supported highest streptokinase activity $(0.372 \mathrm{U} / \mathrm{ml})$ followed by L-lysine and tryptophan. As compared to vitamins like riboflavin and nicotinic acid, thiamine facilitated maximum streptokinase activity $(0.360 \mathrm{U} / \mathrm{ml})$ by $S$. dysgalactiae subsp. equisimilis SK-6 and was selected for further studies. Streptokinase production was greatly reduced when no growth factor was added to the medium (Fig. 2).

Glycine acted as the best amino acid probably because its supplementation enhanced the release of periplasmic proteins such as streptokinase into the medium without causing significant cell lysis (Aristidou et al. 1995).

A previous study on streptokinase fermentation reported that apart from enzyme hydrolyzed casein constituting the major part of production medium, two other ingredients, namely, glycine and an organic sulfhydryl reducing agent were also necessary. The amount of glycine employed in preparing the fermentation medium varied within wide limits, for instance, from 1.0 to 350 parts by weight of glycine for each 1,000 parts by weight of casein digest. The optimum amount had been found to be from about 200 parts of glycine for each 1,000 parts by weight of casein digest (Szumski 1962).

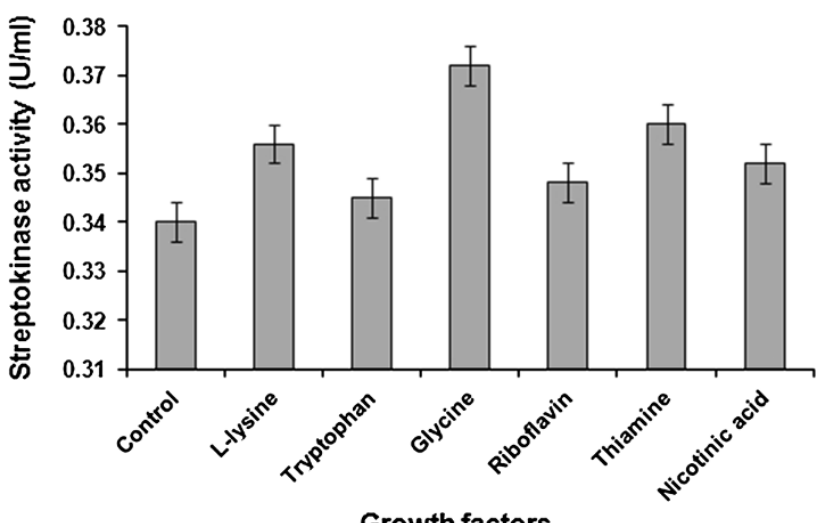

Fig. 2 Effect of different growth factors on streptokinase production. Data represent mean $\pm \mathrm{SD}(n=3) ; P<0.05$

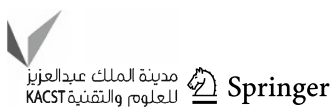


In general, the streptokinase fermentation medium comprised a nitrogen source such as gelatin hydrolysate or casein digest supplemented with various amino acids such as cystine, glycine, tryptophan, tyrosine, methionine and glutamine, uracil and adenine, various salts, glucose and certain members of the vitamin B group (Bernheimer and Pappenheimer 1942).

Thiamine among the vitamins supported highest streptokinase activity by $S$. dysgalactiae subsp. equisimilis SK-6 probably because thiamine acts as the co-enzyme thiamine pyrophosphate (TPP) in the metabolism of carbohydrates and branched-chain amino acids. Specifically the $\mathrm{Mg}^{2+}$ coordinated TPP participates in the formation of $\alpha$-ketols as catalyzed by transketolase and in the oxidation of $\alpha$-keto acids by dehydrogenase complexes (McCormick 1997). Hence, thiamine deficiency in the fermentation media might have resulted in the overall decrease of carbohydrate metabolism by $S$. dysgalactiae subsp. equisimilis SK-6.

In the large-scale production of streptokinase from Lancefield group of streptococci, the fermentation broth comprised growth factors such as adenine sulphate, nicotinic acid, pyridoxine, tryptophan, calcium pantothenate, thiamine $\mathrm{HCl}$, riboflavin and thioglycolic acid (Ablondi and Adam 1955).

\section{Effect of $\mathrm{MgSO}_{4}$ on streptokinase production}

The state of a bioprocess depends on many parameters and variables, but especially on the state of the microorganisms that are in close interaction with their micro-environment, the nature of which is the consequence of the design of the medium (Calik and Ozdamar 1999). Among the medium components, inorganic compounds can contribute to the structure of the metabolites and/or act as cofactors of the enzymes of intracellular reactions. Consequently, the essential cations in combination with their anions strongly affect bioproduct formation by influencing metabolic pathways and changing metabolic fluxes (Calik et al. 2004).

Supplementation of the production medium with $\mathrm{MgSO}_{4}$ had a positive influence on streptokinase production because magnesium ions play critical roles in many aspects of cellular metabolism. They stabilize structures of proteins, nucleic acids and cell membranes by binding to the macromolecule's surface and promote specific structural or catalytic activities of proteins, enzymes, or ribozymes (Cowan 1993). It is also a key to enzymatic reactions in various ways. They can generate magnesium-substrate scaffolds to which enzymes bind. They can bind directly to enzymes and alter their structure or they may direct reactions through specific catalytic roles (Yang et al. 2004).

Addition of different concentrations of $\mathrm{MgSO}_{4}$ to the MSM influenced streptokinase yield. Highest streptokinase

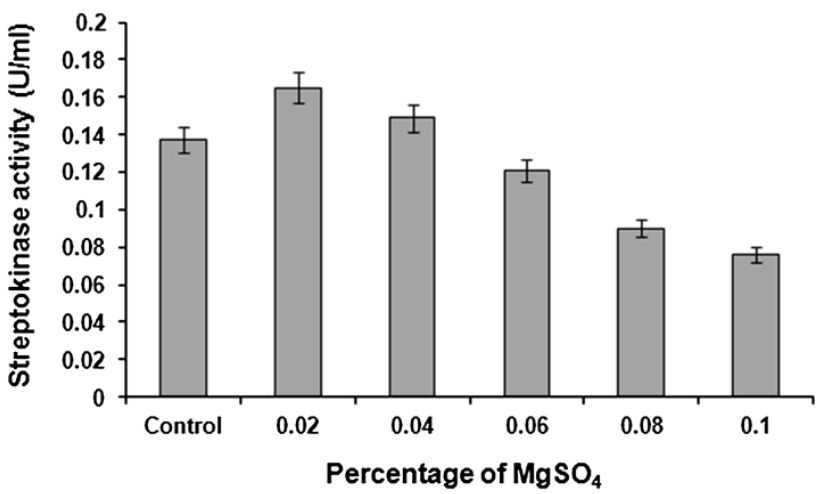

Fig. 3 Effect of $\mathrm{MgSO}_{4}$ supplementation on streptokinase production. Data represent mean $\pm \mathrm{SD}(n=3) ; P<0.05$

activity $(0.165 \mathrm{U} / \mathrm{ml})$ was recorded for $0.02 \%(\mathrm{w} / \mathrm{v})$ $\mathrm{MgSO}_{4}$ supplementation to the medium. Increase in the concentration of $\mathrm{MgSO}_{4}$ beyond $0.02 \%$ resulted in progressive decrease in the streptokinase yield. At the highest concentration of $\mathrm{MgSO}_{4}(0.1 \% \mathrm{w} / \mathrm{v})$, streptokinase production was affected severely (Fig. 3).

$\mathrm{MgSO}_{4}$ at specific concentrations might cause better coupling of supply and demand for the amino acids by regulation of the pathways (Calik et al. 2004). Mahmoudi et al. (2012) reported that higher level of streptokinase $(580 \mu \mathrm{g} / \mathrm{ml})$ was produced in the presence of $\mathrm{MgSO}_{4}$ $(0.25 \mathrm{~g} / 25 \mathrm{ml})$ as compared to the condition when no $\mathrm{MgSO}_{4}$ was added to the medium $(360 \mu \mathrm{g} / \mathrm{ml})$.

\section{Effect of $\mathrm{FeSO}_{4}$ on streptokinase production}

Iron, as the ferrous or ferric ion, is essential for the life processes of all eukaryotes and most prokaryotes. However, the element is toxic when in excess of that needed for cellular homeostasis (Smith 2004). Iron is an essential transition metal in the fermentation medium. It is frequently added to the fermentation medium as a nitrate or sulphate salt. Iron complexes can form with bio-molecules such as amino acids, nucleotides, physiological chelators and proteins. The specific complexes are very important because they determine whether the iron is available to participate in cell growth and catalyze toxic reactions or becomes non-available to the system. Free or ineffectively sequestered iron can be very toxic to cells. Properly complexed iron is available to support cell life and is essential to the cell culture system.

Supplementation of the production medium with $\mathrm{FeSO}_{4}$ enhanced streptokinase production. A gradual increase in streptokinase production was observed between 0.002 and $0.004 \%$ of $\mathrm{FeSO}_{4}$. Highest streptokinase activity $(0.392 \mathrm{U} / \mathrm{ml})$ was obtained with $0.004 \%$ (w/v) $\mathrm{FeSO}_{4}$ supplementation to the medium. Beyond this 


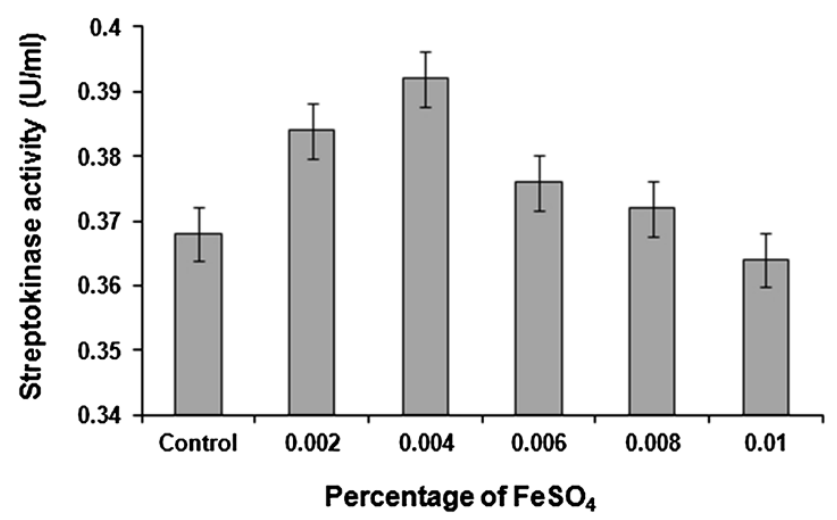

Fig. 4 Effect of $\mathrm{FeSO}_{4}$ supplementation on streptokinase production. Data represent mean $\pm \mathrm{SD}(n=3) ; P<0.05$

concentration, a steady decrease in streptokinase activity was recorded (Fig. 4).

During streptokinase fermentation by $S$. dysgalactiae subsp. equisimilis SK-6, excess of ferrous iron in the medium could have remained unutilized and resulted in the development of oxidative stress, leading to a decrease in streptokinase production. Otherwise, excess ferrous iron might have complexed with thiols such as cysteine to form the ferrous:cysteine complex that generated hydroxyl free radicals through Fenton chemistry which could have initiated lipid peroxidation. The primary effect of lipid peroxidation is decrease in membrane fluidity, which alters membrane properties and can disrupt membrane-bound proteins significantly (Cabiscol et al. 2000).

Trace elements are usually added to the streptokinase fermentation medium in the form of a salt mixture to furnish ions of metals such as iron, magnesium, copper, zinc, etc. in very slight amounts. It is often convenient to prepare a salt mixture from the salts of these metals and add a small quantity of the mixture to each fermentation (Hawkins 1955).

Effect of incubation period on streptokinase production

The incubation time for achieving the maximum enzyme level is governed by the characteristics of the culture and is based on growth rate and enzyme production. The enzyme production varies with incubation time (Kunamneni et al. 2005). It is very essential to detect the optimum incubation time at which an organism exhibits highest enzyme production, since organisms show considerable variation at different incubation periods (Kumar et al. 2012).

Production of streptokinase from $S$. dysgalactiae subsp. equisimilis SK-6 was dependent on the incubation time. Streptokinase yield increased from 24 to $48 \mathrm{~h}$ of incubation, with the highest level of streptokinase production $(0.238 \mathrm{U} / \mathrm{ml})$ reported at $48 \mathrm{~h}$. When the fermentation

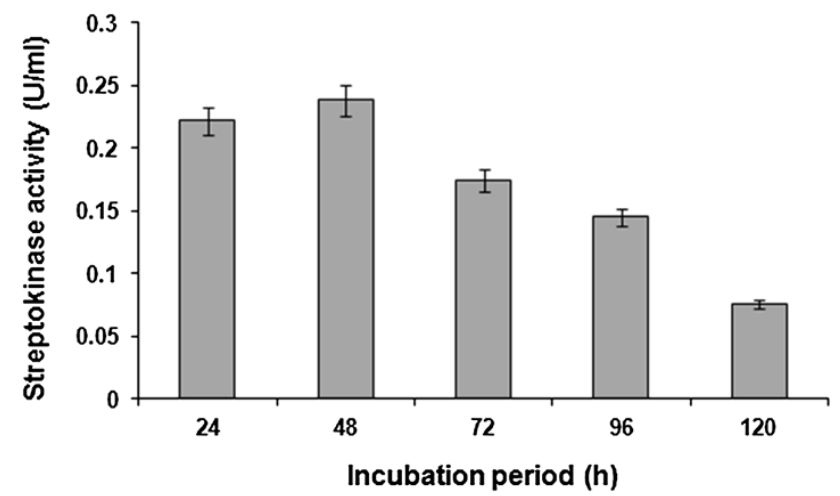

Fig. 5 Effect of incubation period on streptokinase production. Data represent mean $\pm \mathrm{SD}(n=3) ; P<0.05$

proceeded beyond $48 \mathrm{~h}$ there was a decrease in the streptokinase yield (Fig. 5).

The probable reason for decrease in the streptokinase production beyond $48 \mathrm{~h}$ may be due to rapid depletion of nutrients in the medium, accumulation of excess acid in the media as a result of sugar utilization and developed oxygen tension. The reduction in the streptokinase production upon prolonged incubation may be attributed to the induction of Crabtree effect. Literatures suggest that Crabtree effect leads to accumulation of acetate which is inhibitory to cell growth and generation of toxic byproducts that often limit protein yields (Ferreira et al. 2003). Lactic acid inhibition has been included in streptokinase production (Patnaik 1995).

Baewald et al. (1975) used a simple and inexpensive medium to obtain high yields of streptokinase from $S$. equisimilis. The medium contained yeast autolyzate or corn steep liquor as nitrogen source, glucose and various salts. High titres of streptokinase were attained at $28{ }^{\circ} \mathrm{C}, \mathrm{pH}$ 7.2-7.4, within $24 \mathrm{~h}$ in agitated cultures. Production of streptokinase from $S$. pyogenes decreased while increasing the incubation time from 2 to 7 days (Patel et al. 2011).

Effect of inoculum size on streptokinase production

The finite volume of a culture medium means that it can only contain limited nutrients for the microorganism. Furthermore, the consumption of the nutrients is largely dependent on the population of bacteria. To ensure a high production of enzyme in the limited volume of medium, the bacterial inoculum size should therefore be controlled (Abusham et al. 2009).

Inoculation of MSM with various inoculum sizes $(0.05-3 \% \mathrm{v} / \mathrm{v})$ of $S$. dysgalactiae subsp. equisimilis SK-6 affected the production of streptokinase. The highest streptokinase activity $(0.360 \mathrm{U} / \mathrm{ml})$ was achieved with an inoculum size of $1 \%(\mathrm{v} / \mathrm{v})$. A higher inoculum of $3 \%(\mathrm{v} / \mathrm{v})$ was found to reduce the production of streptokinase (Fig. 6). 


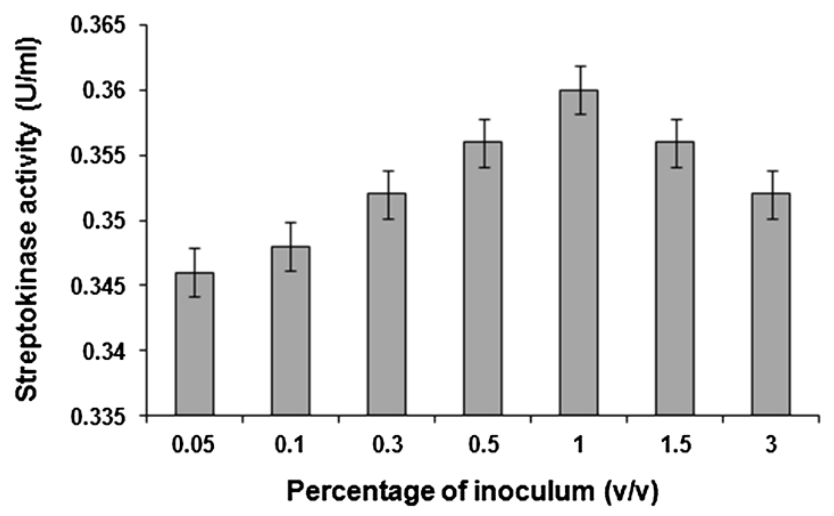

Fig. 6 Effect of inoculum size on streptokinase production. Data represent mean $\pm \mathrm{SD}(n=3) ; P<0.05$

The increase in the production of streptokinase using small inoculum sizes could have been due to the higher surface area to volume ratio, which might have resulted in the increased production of enzyme (Rahman et al. 2005). Therefore, high inoculum sizes do not necessarily give higher streptokinase yield.

In addition, an improved distribution of dissolved oxygen and more effective uptake of nutrients might have contributed to a higher streptokinase yield. If the inoculum sizes are very small, insufficient number of bacteria would lead to a reduced amount of secreted enzyme. However, higher inoculum sizes could lead to or cause a lack of oxygen and depletion of nutrients in the culture medium (Shafee et al. 2005).

Chemically defined media for growing group A streptococci have been developed to require only small inocula and without the need for a prior adaptation regimen. The doubling times of the streptococci in such media can be comparable to those in complex media (McCoy et al. 1991). Similar to our results, Karimi et al. (2011) found that the bacterial strain S. equisimilis H46A (ATCC 12449) produced relatively high yields of streptokinase by the use of $1 \%$ inoculation, $\mathrm{pH}$ adjustment and glucose feeding as compared to $10 \%$ inoculation and $\mathrm{pH}$ adjustment. While optimizing the batch fermentation parameters involved in streptokinase production from $S$. pyogenes, it was concluded that concentration of corn steep liquor and ageing period of the producing strain were the parameters which had positive significant effect on enzyme yield while inoculum volume had negative significant effect on its yield (Patel et al. 2011).

\section{Conclusions}

From the present study it could be inferred that streptokinase production by $S$. dysgalactiae subsp. equisimilis SK-6 was influenced by chemical and physical parameters such as surfactants, growth promoters, trace elements, incubation period and volume of inoculum. Incorporation of nonionic surfactant Tween 80, vitamin, amino acid and trace elements such as thiamine, glycine, $\mathrm{MgSO}_{4}$ and $\mathrm{FeSO}_{4}$ enhanced the enzyme yield. $48 \mathrm{~h}$ of incubation with $1 \%$ $(\mathrm{v} / \mathrm{v})$ inoculum size enhanced streptokinase yield. The strain S. dysgalactiae subsp. equisimilis SK-6 may be successfully utilized for streptokinase production.

Acknowledgments We wish to extend our sincere gratitude to the managements of Karpagam University and Bharathiar University for their encouraging support.

Conflict of interest The authors declare that they have no conflict of interest.

Open Access This article is distributed under the terms of the Creative Commons Attribution License which permits any use, distribution, and reproduction in any medium, provided the original author(s) and the source are credited.

\section{References}

Abdelghani TTA, Kunamneni A, Ellaiah P (2005) Isolation and mutagenesis of streptokinase producing bacteria. Am J Immunol $1: 125-129$

Ablondi FB, Adam JN Jr (1955) Enzyme production. In: United States patent US 2701227 A

Abusham RA, Rahman RNZRA, Salleh AB, Basri M (2009) Optimization of physical factors affecting the production of thermo-stable organic solvent-tolerant protease from a newly isolated halo tolerant Bacillus subtilis strain Rand. Microb Cell Factories 8:20

Aristidou AA, San KY, Bennett GN (1995) Metabolic engineering of Escherichia coli to enhance recombinant protein production through acetate reduction. Biotechnol Prog 11:475-478

Babashamsi M, Razavian MH, Nejadmoghaddam MR (2009) Production and purification of streptokinase by protected affinity chromatography. Avicenna J Med Biotechnol 1:47-51

Baewald G, Mayer G, Heikel R, Volzke KD, Roehlig R, Decker KL (1975) Fermentative production of Streptococcus metabolites, especially streptokinase. In: German patent DD 111096

Banerjee A, Chisti Y, Banerjee UC (2004) Streptokinase-a clinically useful thrombolytic agent. Biotechnol Adv 22:287-307

Bernheimer AW, Pappenheimer AM (1942) Factors necessary for massive growth of group A hemolytic Streptococcus. J Bacteriol 43:481-494

Bhardwaj S, Angayarkanni J, Bhattacharya S, Das A, Palaniswamy M (2013) Isolation, screening and characterization of $\beta$-haemolytic streptococci with potential of streptokinase production. Int Res J Biol Sci 2:63-66

Cabiscol E, Tamarit J, Ros J (2000) Oxidative stress in bacteria and protein damage by reactive oxygen species. Int Microbiol 3:3-8

Calik P, Ozdamar TH (1999) Mass flux balance-based model and metabolic pathway engineering analysis for serine alkaline protease synthesis by Bacillus licheniformis. Enzym Microb Technol 24:621-635

Calik P, Bilir E, Ozcelik IS, Calik G, Ozdamar TH (2004) Inorganic compounds have dual effect on recombinant protein production: influence of anions and cations on serine alkaline protease production. J Appl Microbiol 96:194-200 
Cowan JA (1993) Inorganic biochemistry. An introduction. VCH publishers Inc, New York

Ferreira BS, Calado CR, van Keulen F, Fonseca LP, Cabral JM, da Fonseca MM (2003) Towards a cost effective strategy for cutinase production by a recombinant Saccharomyces cerevisiae: strain physiological aspects. Appl Microbiol Biotechnol 61:69-76

Furie B, Furie BC (2008) Mechanisms of thrombus formation. N Engl J Med 359:938-949

Grundy SM, Benjamin IJ, Burke GL, Chait A, Eckel RH, Howard BV, Mitch W, Smith SC Jr, Sowers JR (1999) Diabetes and cardiovascular disease: a statement for healthcare professionals from the American Heart Association. Circulation 100: $1134-1146$

Hawkins SR (1955) Method of producing streptokinase and streptodornase. In: United States patent US 2702781 A

Jurado E, Fernández-Serrano M, Núñez-Olea J, Luzón G, Lechuga M (2009) Acute toxicity and relationship between metabolites and ecotoxicity during the biodegradation process of non-ionic surfactants: fatty-alcohol ethoxylates, nonylphenol polyethoxylate and alkylpolyglucosides. Water Sci Technol 59:2351-2358

Karimi Z, Babashamsi M, Asgarani E, Niakan M, Salimi A (2011) Fermentation, fractionation and purification of streptokinase by chemical reduction method. Iran J Microbiol 3:42-46

Kumar DJM, Venkatachalam P, Govindarajan N, Balakumaran MD, Kalaichelvan PT (2012) Production and purification of alkaline protease from Bacillus sp. MPTK 712 isolated from dairy sludge. Glob Vet 8:433-439

Kunamneni A, Permaul K, Singh S (2005) Amylase production in solid state fermentation by the thermophilic fungus Thermomyces lanuginosus. J Biosci Bioeng 100:168-171

Lowry OH, Rosebrough NJ, Farr AL, Randall RJ (1951) Protein measurement with the Folin phenol reagent. J Biol Chem 193:265-275

Mackman N (2012) New insights into the mechanisms of venous thrombosis. J Clin Invest 122:2331-2336

Mahmoudi S, Abtahi H, Bahador A, Mosayebi G, Salmanian AH, Teymuri M (2012) Optimizing of nutrients for high level expression of recombinant streptokinase using pET32a expression system. Maedica (Buchar) 7:241-246

McCormick DB (1997) Co-enzymes, biochemistry. In: Dulbecco R (ed) Encyclopedia of human biology, 2nd edn. Academic Press, San Diego, pp 847-864

McCoy HE, Broder CC, Lottenberg R (1991) Streptokinases produced by pathogenic group $\mathrm{C}$ streptococci demonstrate species-specific plasminogen activation. J Infect Dis 164:515-521
Mounter LA, Shipley BA (1958) The inhibition of plasmin by toxic phosphorus compounds. J Biol Chem 231:855-861

Oberoi R, Beg QK, Puri S, Sexena RK, Gupta R (2001) Characterization and wash performance analysis of an SDS-stable alkaline protease from a Bacillus sp. World J Microbiol Biotechnol 17:493-497

Patel VP, Patel KS, Patel RM (2011) Isolation and optimization of streptokinase production by batch fermentation. Int J Pharm Biol Arch 2:1488-1492

Patnaik PR (1995) A heuristic approach to fed-batch optimization of streptokinase fermentation. Bioprocess Eng 13:109-112

Phan TT, Ta TD, Nguyen DT, Van Den Broek LA, Duong GT (2011) Purification and characterization of novel fibrinolytic proteases as potential antithrombotic agents from earthworm Perionyx excavatus. AMB Express 1:26

Rahman RN, Geok LP, Basri M, Salleh AB (2005) Physical factors affecting the production of organic solvent-tolerant protease by Pseudomonas aeruginosa strain K. Bioresour Technol 96:429-436

Rao UMJL, Satyanarayana T (2003) Statistical optimization of a high maltose-forming, hyperthermostable and $\mathrm{Ca}^{2+}$-independent alpha-amylase production by an extreme thermophile Geobacillus thermooleovorans using response surface methodology. J Appl Microbiol 95:712-718

Reddy LV, Wee YJ, Yun JS, Ryu HW (2008) Optimization of alkaline protease production by batch culture of Bacillus sp. RKY3 through Plackett-Burman and response surface methodological approaches. Bioresour Technol 99:2242-2249

Shafee N, Aris SN, Rahman RNZA, Basri M, Salleh AB (2005) Optimization of environmental and nutritional conditions for the production of alkaline protease by a newly isolated bacterium Bacillus cereus strain 146. J Appl Sci Res 1:1-8

Singh A, Van Hamme JD, Ward OP (2007) Surfactants in microbiology and biotechnology: part 2. Application aspects. Biotechnol Adv 25:99-121

Smith JL (2004) The physiological role of ferritin-like compounds in bacteria. Crit Rev Microbiol 30:173-185

Szumski SA (1962) Method of producing streptokinase and streptodornase. In: United States patent US 3046200 A

Tharwat NA (2006) Purification and biochemical characterization of fibrinolytic enzyme produced by thermophilic fungus Oidiodendron flavum. Biotechnology 5:160-165

Yang L, Arora K, Beard WA, Wilson SH, Schlick T (2004) Critical role of magnesium ions in DNA polymerase $\beta$ 's closing and active site assembly. J Am Chem Soc 126:8441-8453 